\title{
THE NATURE OF “PREFORMED WATER”
}

\author{
By JOHN P. PETERS and PAUL H. LAVIETES * \\ (From the Department of Internal Medicine, Yale University \\ School of Medicine, New Haven)
}

(Received for publication March 23, 1933)

In the method which Newburgh and Johnston $(1,2)$ have proposed for the calculation of water exchange, they define the latter as consisting of three components: 1 , preexisting water from the external environment; 2, water formed de novo by the oxidation of food stuffs; 3 , "preformed water." This last term is applied to water which already existed as such in the tissues, presumably acting as a solvent for protoplasmic substances in the cells and as both solvent and vehicle in the circulating fluids and extracellular (or interstitial) fluids. This fluid or some fraction of it, they postulate, is intimately associated with protein, fat and carbohydrate (glycogen) in the tissues and is liberated when the latter are burned. Conversely it may be presumed that a fraction of the extraneous water becomes bound when the body content of these substances increases. It has been pointed out (3) in a simple analysis of the form of their mathematical calculations that it may be advisable, for certain purposes, at least, to distinguish this third fraction of water from the others because it belongs in a different category. For this reason two equations were proposed, based on Newburgh and Johnston's methods of calculation. The first of these expresses the change in the total quantity of water in the body:

$$
\text { 1. } W B=\left(W_{2}-W_{1}\right)+\left(S_{e}-S_{f}\right)+\left(F_{b}+C_{b}+0.49 P_{b}\right) \text {, }
$$

in which $W B$ represents water balance; $W_{1}$ and $W_{2}$ initial and final body weights, respectively; $S_{f}$ and $S_{e}$ the solids ingested and excreted, respectively; and $F_{b}, C_{b}$ and $P_{b}$ the quantities of fat, carbohydrate and protein burned during the course of observation. The composition of the metabolic mixture is estimated from the insensible perspiration, the nitrogen excretion and the carbohydrate content of the diet, in the manner proposed by Newburgh and Johnston.

Preformed water $(P W)$ is estimated from the body tissue destroyed by the following equation:

$$
\text { 2. } P W=3\left(P_{b}-P_{f}\right)+0.1\left(F_{b}-F_{f}\right)+3\left(C_{b}-C_{f}\right) \text {, }
$$

where the subscripts $b$ and $f$ stand for burned and fed, respectively. The composition of the ingesta is calculated from dietary tables or determined by analysis, that of the metabolic mixture by the method of calculation out-

\footnotetext{
* Sax Research Fellow in Clinical Medicine.
} 
lined under Equation 1. The factors for water held by protein and by fat are those used by Newburgh and Johnston; the factor for carbohydrate, the one commonly employed, is ascribed to Zuntz, Loewy, Müller and Caspari (4), and based on experimental data of Pavy (5). In their own studies Newburgh and Johnston have assumed that all ingested carbohydrate is burned, the body glycogen content remaining unchanged. Under these circumstances $C_{b}=C_{f}$ and the last term of Equation 2 disappears.

If it is desired to follow the principles of Newburgh and Johnston exactly, $P W$ may be added to the right hand side of Equation 1 . The inclusion of this term in the water balance equation has certain implications. It assumes that this especial fraction of water is distinguished from the remaining water in the body by the fact that its freedom is restricted. It is restrained or held by the proteins, fats and glycogen of the tissues and regains its liberty only when these are oxidized. In this connection Newburgh and Johnston state that the fluid is held in "physical combination" with protein and fat. It would seem to be implicit in their definition also, that when this water was freed by combustion of tissues it would reassume the character of ordinary water and be discharged in the excreta. In this manner the dilution of solids in the body water would remain relatively constant. This second concept of a mechanism that maintains the dilution of cellular protoplasm relatively constant is more explicitly voiced by others who have entertained similar theories.

It is the purpose of this paper to examine critically the evidence upon which the concept of "preformed water" and the mathematical factors by which it is estimated are based.

It may not be amiss to point out that the term "preformed water" is a somewhat unhappy one to express the meaning of Newburgh and Johnston. Benedict (6) applied it more correctly to all the fractions of water included in the water balance with the exception of water of oxidation which is formed de novo by the metabolism of food solids. He applied the term "loss of preformed water" to intrinsic body water which was discharged in the excreta, a fraction which is somewhat comparable to, but not identical with, the "preformed water" of Newburgh and Johnston. In order to avoid some confusion in the subsequent discussion it may be well to speak of the general concept embodied in Newburgh and Johnston's use of this term as the " theory of combined water." This would seem to be justified by their statement ( 2 , p. 85$)$ that " every gram of body protein holds in physical combination three grams of water; and every gram of body fat, one-tenth of one gram of water." In another place (p. 79) they say, "The hydrophyllic colloid protein holds water equal to three times its weight, whereas body fat holds only ten per cent of its weight in water," more clearly defining the nature of the combination. The term preformed water, when used without specific definition, refers to the fraction so designated by Newburgh and Johnston. 
Identical authorities are rather universally cited in support of the theory of combined water. In fact many of the adherents of this theory have been content to refer to the rather general statements of Lusk (7) upon the subject. The evidence as a whole can be separated into two distinct categories. In the first belong metabolism experiments in which alteration of body tissue is associated with the discharge or assumption of a certain amount of water. Although Newburgh and Johnston and other adherents of the theory of combined water do not specifically declare that combined water, when released, is necessarily excreted, citation of evidence of this nature implies that it is excreted and that, conversely, an equivalent amount of water is retained when food stuffs are stored or when tissue is formed or regenerated. The second kind of evidence is contributed by analyses of tissues. Both these types of evidence will be examined in detail and this examination will include not only the usual authorities, but other relevant data from the literature and from experiments carried out in this department.

Evidence from metabolism experiments that alterations of the tissue mass are attended by quantitatively equivalent changes of the water content of the body

If alterations of the body tissue mass were of necessity attended by equivalent changes of the water content of the body, it would follow that $W B$ and $P W$ should be equal, or at least quantitatively related to one another, during conditions of changing nutrition.

Lusk (7), on p. 355, cites a metabolism experiment of Benedict and Milner (8), which is again cited by Gamble (9) and others, apparently from Lusk. In this experiment the subject received for 3 days a diet containing 66 per cent of its calories in the form of carbohydrate, after which he was transferred for a second period of 3 days to a diet with 67 per cent of the calories in the form of fat. During both periods the subject worked. Summaries of these experiments as well as an additional work day on the fat diet and 4 days of rest on the carbohydrate diet are given in Table 1. The data and calculations of columns 1 to 4 are those of Benedict

TABLE 1

Table of estimated gains and losses of body material, from Benedict and Milner (8), page 224

\begin{tabular}{|c|c|c|c|c|c|c|c|c|}
\hline $\begin{array}{c}\text { Experi- } \\
\text { ment }\end{array}$ & Days & $\begin{array}{c}1 \\
\text { Protein }\end{array}$ & $\begin{array}{c}2 \\
\text { Fat }\end{array}$ & $\begin{array}{c}3 \\
\text { Carbo- } \\
\text { hydrate }\end{array}$ & $\underset{(B+M)}{\stackrel{4}{\text { Water }}}$ & $\begin{array}{c}5 \\
\text { Water }\end{array}$ & $\begin{array}{c}6 \\
\text { P.W. }\end{array}$ & Nature of diet \\
\hline 62 & 3 & $\begin{array}{l}\text { grams } \\
-16\end{array}$ & $\begin{array}{l}\text { grams } \\
-75\end{array}$ & $\begin{array}{r}\text { grams } \\
-150\end{array}$ & $\begin{array}{l}\text { grams } \\
496\end{array}$ & $\begin{array}{l}\text { grams } \\
\quad 610\end{array}$ & $\begin{array}{l}\text { grams } \\
-506\end{array}$ & $\begin{array}{l}66 \text { per cent carbohydrate. } \\
\text { Patient working }\end{array}$ \\
\hline $\begin{array}{l}63 \\
64\end{array}$ & $\begin{array}{l}3 \\
1\end{array}$ & $\begin{array}{r}-36 \\
15\end{array}$ & $\begin{array}{l}-140 \\
-131\end{array}$ & $\begin{array}{l}-8 \\
-229\end{array}$ & $\begin{array}{r}-2719 \\
531\end{array}$ & $\begin{array}{r}-2554 \\
531\end{array}$ & $\left|\begin{array}{l}-146 \\
-629\end{array}\right|$ & $\left\{\begin{array}{l}67 \text { per cent fat. Patient } \\
\text { working }\end{array}\right.$ \\
\hline $65-67$ & 4 & -198 & -352 & 410 & 298 & 407 & 601 & $\begin{array}{l}66 \text { per cent carbohydrate. } \\
\text { Patient working }\end{array}$ \\
\hline Total & & -235 & -698 & 24 & -1456 & -1006 & -680 & \\
\hline
\end{tabular}


and Milner (8), taken directly from their table on p. 224. Water loss in column 4 is calculated by Benedict and Milner from the determined balances of the elements $\mathrm{C}, \mathrm{H}, \mathrm{N}$ and $\mathrm{O}$ by the formula,

$$
\text { Water }=-1.248 \mathrm{C}+7.92 \mathrm{H}+0.128 \mathrm{O}_{2}+0.460 \mathrm{~N} \text {, }
$$

the derivation of which is discussed on pp. 71-72 of the bulletin. This determines total body water change within the error of the analytical methods. In the first carbohydrate period the subject retained 496 grams of water, or 165 grams per day; while in the succeeding fat period he lost 2719 grams, or 906 grams per day. Benedict's remarks about the experiment are quite conservative, implying only that animals retain more water in their tissues when they are fed carbohydrate. Lusk $(7$, p. 355), adds the statement, "A loss of body glycogen is, therefore, associated with a loss of body weight." Examination of the data reveals the fact that, in spite of the water retention in the carbohydrate period, there was an estimated loss of 150 grams of carbohydrate, which can only have emanated from glycogen stores; while in the fat period only 8 grams were lost. Obviously, then, the water retention of the carbohydrate period was not connected with glycogen deposition, nor was the water loss of the fat period referable to glycogen depletion.

.Water loss in column 5 , Table 1 , is calculated by subtracting from Benedict and Milner's "loss of preformed water" the calculated water of oxidation of the food stuffs burned. The analyses involved in this calculation should be less subject to error than those involved in Benedict and Milner's calculation. In column 6 preformed water is calculated from the conventional factors by Equation 2 . This does not agree at all with the actual water loss estimated by either method of calculation.

In a monograph on inanition Benedict (6) uses the term "loss of preformed water" to express the negative balance of water which was not derived from the oxidation of food stuffs, i.e. $-\left(W B-\mathrm{H}_{2} \mathrm{O}_{\text {ox. }}\right)$. He recognizes that, except for the water of oxidation, all water of ingesta, excreta and body contents is preformed water. Consequently he speaks of the water of the excreta (including the loss by lungs and skin) minus the water of oxidation as "preformed (katabolized) water in outgo." In a series of experiments upon the metabolism of normal subjects during starvation he compares the "loss of preformed water" with what he calls "water in flesh," that is, the water that would be held in muscle containing protein in amounts equivalent to the nitrogen lost in the excreta. For this calculation he assumes that "each gram of protein is combined with water to form 4.9 grams of flesh." Therefore "water in flesh" $=(3.9$ $\times 6.25 \times \mathrm{N}$ in the excreta). In Table 2 values of "water in flesh" (column 2) are compared with "loss of preformed water" (column 1) and the differences between the two are given in column 5 . These values are taken directly from the table on p. 469 of the monograph. Total body 
TABLE 2

Comparison of water excretion and body tissue changes from data of Benedict (6)

\begin{tabular}{|c|c|c|c|c|c|c|c|c|}
\hline \multirow[b]{2}{*}{$\begin{array}{c}\text { Experi- } \\
\text { ment } \\
\text { number }\end{array}$} & \multicolumn{5}{|c|}{ Loss of } & \multicolumn{3}{|c|}{ Discrepancies } \\
\hline & Days & $\begin{array}{c}1 \\
\text { Preformed } \\
\text { water } \\
\text { (meas- } \\
\text { ured) }\end{array}$ & $\begin{array}{c}2 \\
\text { Water } \\
\text { in flesh } \\
(3.9+P)\end{array}$ & $\begin{array}{c}\text { 3 } \\
\text { Preformed } \\
\text { water (meas- } \\
\text { ured) - water } \\
\text { of oxidation }\end{array}$ & $\begin{array}{c}4 \\
\text { Preformed water } \\
3(P+C)+0.1 F\end{array}$ & $\begin{array}{c}5 \\
1-2\end{array}$ & $\begin{array}{c}6 \\
3-2\end{array}$ & $\begin{array}{c}7 \\
3-4\end{array}$ \\
\hline & & grams & grams & grams & grams & grams & grams & grams \\
\hline \multicolumn{9}{|c|}{ Starving subjects } \\
\hline 59 & $\begin{array}{l}1 \\
2 \\
3\end{array}$ & $\begin{array}{l}905 \\
296 \\
404\end{array}$ & $\begin{array}{l}277 \\
330 \\
347\end{array}$ & $\begin{array}{r}676 \\
73 \\
182\end{array}$ & $\begin{array}{l}496 \\
448 \\
298\end{array}$ & $\begin{array}{r}628 \\
-\quad 34 \\
57\end{array}$ & $\begin{array}{r}399 \\
-257 \\
-165\end{array}$ & $\begin{array}{r}180 \\
-375 \\
-116\end{array}$ \\
\hline \multirow[t]{2}{*}{68} & 1 & 1192 & 287 & 951 & 573 & 905 & 664 & 378 \\
\hline & 2 & 703 & 305 & 466 & 469 & 398 & 161 & -3 \\
\hline \multirow[t]{3}{*}{69} & $\begin{array}{l}1 \\
2\end{array}$ & $\begin{array}{l}286 \\
659\end{array}$ & $\begin{array}{l}236 \\
334\end{array}$ & $\begin{array}{r}65 \\
428\end{array}$ & $\begin{array}{l}506 \\
369\end{array}$ & $\begin{array}{r}50 \\
325\end{array}$ & $\begin{array}{r}-171 \\
94\end{array}$ & $\begin{array}{r}-441 \\
59\end{array}$ \\
\hline & 3 & 203 & 352 & -18 & 385 & -149 & -370 & -403 \\
\hline & 4 & 386 & 304 & 173 & 296 & 82 & -131 & -123 \\
\hline \multirow[t]{3}{*}{71} & 1 & 440 & 137 & 205 & 662 & 303 & 68 & -457 \\
\hline & $\begin{array}{l}2 \\
3\end{array}$ & $\begin{array}{l}476 \\
564\end{array}$ & $\begin{array}{l}258 \\
307\end{array}$ & $\begin{array}{l}276 \\
373\end{array}$ & $\begin{array}{l}303 \\
316\end{array}$ & $\begin{array}{l}218 \\
257\end{array}$ & $\begin{array}{l}18 \\
66\end{array}$ & $\begin{array}{r}-27 \\
57\end{array}$ \\
\hline & 4 & 306 & 251 & 130 & 282 & 55 & -121 & -152 \\
\hline \multirow[t]{4}{*}{73} & 1 & 618 & 241 & 408 & 602 & 377 & 167 & -194 \\
\hline & $\begin{array}{l}2 \\
3\end{array}$ & 621 & 280 & 425 & 285 & 341 & $\begin{array}{r}145 \\
-100\end{array}$ & 140 \\
\hline & $\begin{array}{l}3 \\
4\end{array}$ & $\begin{array}{l}349 \\
362\end{array}$ & $\begin{array}{l}270 \\
243\end{array}$ & $\begin{array}{l}161 \\
182\end{array}$ & $\begin{array}{l}245 \\
266\end{array}$ & $\begin{array}{r}79 \\
119\end{array}$ & $\begin{array}{l}-109 \\
-161\end{array}$ & $\begin{array}{l}-84 \\
-84\end{array}$ \\
\hline & 5 & 300 & 234 & 130 & 165 & 66 & -104 & -35 \\
\hline \multirow[t]{7}{*}{75} & 1 & -48 & 286 & -243 & 428 & -334 & -529 & -671 \\
\hline & 2 & 564 & 291 & 375 & 308 & 273 & 84 & 67 \\
\hline & 3 & 529 & 305 & 342 & 266 & 224 & 37 & 76 \\
\hline & 4 & 453 & 272 & 268 & 300 & 181 & -4 & -32 \\
\hline & 5 & 216 & 254 & 43 & 235 & -38 & -211 & -182 \\
\hline & 6 & 255 & 251 & 189 & 271 & 4 & -62 & -82 \\
\hline & 7 & 239 & 237 & 75 & 252 & 2 & -162 & -177 \\
\hline \multirow[t]{4}{*}{77} & 1 & 942 & 206 & 734 & 450 & 736 & 526 & 284 \\
\hline & 2 & 965 & 252 & 763 & 256 & 713 & 511 & 507 \\
\hline & 3 & 927 & 257 & 735 & 388 & 670 & 478 & 347 \\
\hline & 4 & 578 & 268 & 390 & 299 & 310 & 122 & 91 \\
\hline \multirow[t]{2}{*}{79} & 1 & 661 & 190 & 441 & 512 & 471 & 251 & -71 \\
\hline & 2 & 959 & 336 & 744 & 394 & 623 & 408 & 350 \\
\hline \multirow[t]{2}{*}{80} & 1 & 1682 & 182 & 1465 & 465 & 1500 & 1283 & 1000 \\
\hline & 2 & 1365 & 233 & 1141 & 249 & 1132 & 908 & 892 \\
\hline \multirow[t]{2}{*}{81} & 1 & 753 & 213 & 567 & 265 & 540 & 354 & 302 \\
\hline & 2 & 1082 & 305 & 903 & 174 & 777 & 598 & 729 \\
\hline \multirow[t]{2}{*}{82} & 1 & 267 & 220 & 11 & 680 & 49 & -209 & -669 \\
\hline & 2 & 1327 & 336 & 1066 & 413 & 991 & 730 & 653 \\
\hline \multirow[t]{2}{*}{83} & 1 & 168 & 310 & -41 & 353 & -142 & -351 & -394 \\
\hline & 2 & 603 & 317 & 406 & 383 & 286 & 89 & 23 \\
\hline \multirow[t]{2}{*}{85} & 1 & 1010 & 266 & 770 & 655 & 744 & 504 & 115 \\
\hline & 2 & 497 & 266 & 245 & 496 & 231 & -21 & -251 \\
\hline \multirow[t]{2}{*}{88} & 1 & 1056 & 234 & 808 & 690 & 822 & 574 & 118 \\
\hline & & 694 & 338 & 450 & 398 & 356 & 112 & 52 \\
\hline
\end{tabular}


TABLE 2-(Continued)

\begin{tabular}{|c|c|c|c|c|c|c|c|c|}
\hline \multirow[b]{2}{*}{$\begin{array}{c}\text { Experi- } \\
\text { ment } \\
\text { number }\end{array}$} & \multicolumn{5}{|c|}{ Loss of } & \multicolumn{3}{|c|}{ Discrepancies } \\
\hline & Days & $\begin{array}{c}1 \\
\text { Preformed } \\
\text { water } \\
\text { (meas- } \\
\text { ured) }\end{array}$ & $\begin{array}{c}2 \\
\text { Water } \\
\text { in flesh } \\
(3.9+P)\end{array}$ & $\begin{array}{c}\text { 3 } \\
\text { Preformed } \\
\text { water (meas- } \\
\text { ured) - water } \\
\text { of oxidation }\end{array}$ & $\begin{array}{c}4 \\
\text { Preformed water } \\
3(P+C)+0.1 F\end{array}$ & $\begin{array}{c}5 \\
1-2\end{array}$ & $\begin{array}{c}6 \\
3-2\end{array}$ & $\begin{array}{c}7 \\
3-4\end{array}$ \\
\hline & & grams & grams & grams & grams & grams & grams & grams \\
\hline \multicolumn{9}{|c|}{ Subjects receiving food following starvation periods } \\
\hline $\begin{array}{l}72 \\
74\end{array}$ & $\begin{array}{l}1 \\
2 \\
3 \\
1 \\
1 \\
2 \\
3 \\
1 \\
2 \\
2 \\
3\end{array}$ & $\begin{array}{r}160 \\
204 \\
-150 \\
38 \\
-52 \\
-106 \\
-127 \\
179 \\
-285 \\
19\end{array}$ & $\begin{array}{r}1141 \\
37 \\
46 \\
110 \\
112 \\
19 \\
54 \\
120 \\
50 \\
65\end{array}$ & $\begin{array}{l}-66 \\
-40 \\
-425 \\
-150 \\
-236 \\
-291 \\
-314 \\
-12 \\
-479 \\
-196\end{array}$ & $\begin{array}{r}34 \\
-68 \\
98 \\
-90 \\
-225 \\
-\quad 89 \\
-154 \\
-303 \\
-135 \\
134\end{array}$ & $\begin{array}{r}46 \\
167 \\
-196 \\
-72 \\
-164 \\
-125 \\
-181 \\
59 \\
-335 \\
-46\end{array}$ & $\begin{array}{l}-180 \\
-77 \\
-471 \\
-260 \\
-348 \\
-311 \\
-368 \\
-132 \\
-529 \\
-261\end{array}$ & $\begin{array}{r}-100 \\
28 \\
-523 \\
-60 \\
-11 \\
-202 \\
-160 \\
291 \\
-344 \\
-330\end{array}$ \\
\hline
\end{tabular}

1 In Benedict's table on page 469 , total protein burned has been multiplied by 3.9. Here this has been corrected to (protein lost) $\times 3.9$.

water loss has been calculated in column 3 and the difference between this and "water of flesh" in column 6 . This seems a more logical method of comparison than that of Benedict, since the presumptive relationship is between total water and total protein of the body. There is little agreement between "water of flesh" and "loss of preformed water" or total loss of water from the body. Especially in the first and second days of fasting the proportion of water to nitrogen is far greater in excreta than it is in tissues. In column 4 preformed water has been calculated by Equation 2 and the difference between this and the total body water loss is given in column 7. Although the discrepancies in the first fast days are, on the average, smaller when they are calculated in this manner, agreement between calculated and observed water losses is still far from satisfactory.

In these experiments, of course, the results of inanition are complicated by the occurrence of starvation acidosis. Acidosis, even without inanition, causes diuresis and body water depletion, in which the extracellular fluids of the body are supposed to be chiefly affected. This aspect of the subject will be considered later. The last four experiments in Table 2 were made on patients who received food. These followed directly after fasting experiments on the same subjects and therefore represent recovery periods. Large discrepancies between calculated and observed water losses are again found, but these tend to be of the opposite sign from those of the fasting experiments. This is in keeping with the influence of acidosis suggested above. Another possible factor helping to produce the excessive loss of water noted at the onset of starvation may be an exaggeration of the slight loss noted when the salt content of the diet is diminished. 
Lusk (7), on p. 105, estimates the "mineral content of the flesh computed to have been destroyed on three different days" of the fast of Benedict's (10) subject $L$, and compares these calculated values with the minerals actually excreted in the urines of these days. For the calculations he uses the human muscle analyses of Katz (11). Lusk concludes that the quantities of potassium, magnesium and sulfur eliminated in the urine are essentially in agreement with those which would have been derived from the destruction of the amount of muscle tissue which would have provided the nitrogen found in the urine. The sodium excretion was much smaller. This experiment has been frequently cited by others as an illustration of the association between losses of tissue substances and water. In Table 3

TABLE 3

Water balance (Benedict's fasting man, $L$ (10))

\begin{tabular}{|c|c|c|c|c|c|c|c|c|c|c|c|}
\hline \multirow{3}{*}{ Days } & \multirow{3}{*}{$\begin{array}{l}1 \\
\text { Teight } \\
\text { alance }\end{array}$} & \multirow{3}{*}{$\begin{array}{l}\text { Urinary } \\
\text { solids }\end{array}$} & 3 & 4 & 5 & \multirow{3}{*}{$3 C$} & \multirow{3}{*}{$\begin{array}{c}7 \\
3 P\end{array}$} & \multirow{3}{*}{$\begin{array}{c}8 \\
0.1 F\end{array}$} & \multirow{3}{*}{$\begin{array}{c}9 \\
1+2+3 \\
+4+5 \\
\text { W.B. }\end{array}$} & \multirow{3}{*}{$\begin{array}{c}10 \\
6+7+8 \\
\text { P.W. }\end{array}$} & \multirow{3}{*}{$\begin{array}{c}9-10 \\
\text { W.B. } \\
\text { minus } \\
\text { P.W. }\end{array}$} \\
\hline & & & \multicolumn{3}{|c|}{ Food burned } & & & & & & \\
\hline & & & $F$ & $C$ & $0.49 P$ & & & & & & \\
\hline & grams & grams & grams & grams & grams & grams & grams & grams & grams & grams & grams \\
\hline 1 & -1040 & 30 & 135 & 69 & 21 & 206 & 128 & 14 & 785 & 348 & 437 \\
\hline 2 & -920 & 31 & 142 & 42 & 25 & 126 & 151 & 14 & 680 & 291 & 389 \\
\hline 3 & -890 & 34 & 130 & 39 & 33 & 115 & 204 & 13 & 654 & 332 & 322 \\
\hline 4 & -760 & 39 & 136 & 4 & 35 & 13 & 214 & 14 & 546 & 241 & 305 \\
\hline 5 & -660 & 34 & 133 & 15 & 31 & 45 & 188 & 13 & 447 & 246 & 201 \\
\hline 6 & -480 & 32 & 133 & & 30 & & 183 & 13 & 285 & 196 & 89 \\
\hline 7 & -390 & 28 & 134 & & 29 & & 176 & 13 & 199 & 189 & 10 \\
\hline 8 & -420 & 30 & 127 & 4 & 30 & 12 & 185 & 13 & 229 & 210 & 19 \\
\hline 9 & -450 & 32 & 119 & 14 & 32 & 41 & 193 & 12 & 253 & 246 & 7 \\
\hline 10 & -500 & 30 & 120 & 4 & 30 & 11 & 181 & 12 & 316 & 204 & 112 \\
\hline 11 & -250 & 29 & 115 & 4 & 30 & 11 & 185 & 12 & 72 & 208 & -136 \\
\hline 12 & -320 & 27 & 118 & 4 & 30 & 11 & 182 & 12 & 141 & 205 & -64 \\
\hline 13 & -110 & 29 & 111 & 3 & 30 & 11 & 186 & 11 & -63 & 208 & -271 \\
\hline 14 & -300 & 28 & 117 & & 31 & & 188 & 12 & 124 & 200 & -76 \\
\hline 15 & -310 & 22 & 116 & & 25 & & 152 & 12 & 147 & 164 & -17 \\
\hline 16 & -580 & 28 & 112 & & 28 & & 173 & 11 & 412 & 184 & 228 \\
\hline 17 & -470 & 27 & 112 & & 26 & & 159 & 11 & 305 & 170 & 135 \\
\hline 18 & -290 & 34 & 109 & & 24 & & 149 & 11 & 123 & 160 & -37 \\
\hline 19 & -390 & 23 & 109 & & 25 & & 151 & 11 & 233 & 162 & 71 \\
\hline 20 & -180 & 20 & 110 & & 20 & & 138 & 11 & 30 & 149 & -119 \\
\hline 21 & -440 & 23 & 112 & & 23 & & 143 & 11 & 282 & 154 & 128 \\
\hline 22 & -360 & 22 & 108 & & 23 & & 140 & 11 & 207 & 151 & 36 \\
\hline 23 & -170 & 20 & 109 & & 22 & & 132 & 11 & 19 & 143 & -124 \\
\hline 24 & -340 & 23 & 109 & & 24 & & 147 & 11 & 184 & 158 & 26 \\
\hline 25 & -290 & 21 & 109 & & 23 & & 141 & 11 & 137 & 152 & -15 \\
\hline 26 & -310 & 23 & 109 & & 23 & & 142 & 11 & 155 & 153 & 2 \\
\hline 27 & -320 & 22 & 109 & & 24 & & 145 & 11 & 165 & 156 & 9 \\
\hline 28 & -240 & 21 & 114 & & 22 & & 137 & 11 & 83 & 148 & -65 \\
\hline 29 & -360 & 21 & 110 & & 22 & & 136 & 11 & 207 & 147 & 60 \\
\hline 30 & -410 & 20 & 108 & & 23 & & 141 & 11 & 259 & 152 & 107 \\
\hline 31 & -300 & 19 & 105 & & 20 & & 125 & 12 & 146 & 137 & 9 \\
\hline
\end{tabular}


$W B$ and $P W$ have been calculated by the usual Equations 1 and 2 . In this special case $S_{f}, P_{f}, C_{f}$ and $F_{f}$ are all equal to zero, because the subject was starving. In the first five days $W B$ far exceeds $P W$, although the difference diminishes as the study proceeds. This rapid initial loss of water may be referable to starvation acidosis. In the last 26 days of the fast the loss. of water is less rapid and more constant, although the discrepancies are variable and sometimes considerable At the end of the experiment altogether $1900 \mathrm{cc}$. of fluid has been lost in excess of the preformed water estimated by Newburgh and Johnston's formula with the conventional additional correction for glycogen losses. If the latter is not included the excess loss will amount to $1200 \mathrm{cc}$. If the average amount excreted during the last 26 days is considered to be the actual loss, per day, of fluid associated with tissue destruction, the total at the same rate for 31 days would be 170 cc., leaving 1730 as the amount swept out by the acidosis.

In all the experiments on starvation cited above, a certain amount of water was lost by the body, but this did not bear any constant relationship to protein or to total tissue burned. Experiments of this nature could be multiplied by adding those of Gamble, Ross and Tisdall (9), and others, but all show essentially the same thing. In the few experiments of Benedict and Milner (8) in which smaller amounts of tissue substance were wasted by subjects on submaintenance diets without starvation and its attendant acidosis, losses of body water were widely divergent from the expected fluid losses calculated from loss of body tissue (see Table 1). Marked discrepancies were also noted in recovery from inanition (see last 4 cases in Table 2). The latter, moreover, were of opposite sign from those found in the fasting experiments. On the whole the experiments which are usually cited and which have been analyzed above give but scanty support to the contention that the relation of body water to tissue solids remains constant during periods of changing nutrition and that the organism gives off or takes on water in any exact mathematical proportion to protein, carbohydrate and fat losses or gains.

It would seem logical to believe that if water were held by proteins in physical combination it could be released, other factors remaining constant, only if protein were destroyed or eliminated. It has already been demonstrated that in the early stages of starvation, water in excess of the theoretical amounts is excreted. This has been ascribed to the diuretic effect of starvation acidosis. As comparable diureses have been observed to follow the use of acidifying salts $(12,13)$ this explanation seems plausible. It would, however, seem to imply that acidification diminishes the water combining powers of the tissue substances. It has recently been shown that similar discharges of water follow other diuretics which have no acidifying effects (14). To conclude on these grounds alone that all or most diuretic agents reduce the hydrophilic properties of tissue colloids would seem unwarranted. 


\section{The nature and quantity of combined (or "preformed") water}

There is no very satisfactory evidence that there is in the body any appreciable amount of water that is distinguished from the remaining water as far as its solvent powers and other properties are concerned. Evidence against the presence of such chemically combined or bound water is found in the distribution of diffusible substances in the aqueous media. Moreover, one of those media has been subjected to more careful in vitro examination $(15,16)$. The subject has been reviewed by Hill (17), who comes to the conclusion that " nearly the whole of the water of muscle is 'free,' in the sense that it can dissolve in a normal manner substances added to it." If, then, there is combined water, the combination must be a loose one and might better be termed biological than physical in the present state of our knowledge.

There is, apparently, recognition of this fact in the treatment accorded the subject by Gamble $(9,12,13)$ and certain other workers, who have estimated losses of intracellular fluid as distinguished from interstitial fluid by multiplying the protein lost from the body by the factor 3 , the same factor which Newburgh and Johnston use to estimate combined water. The restraining influence is transferred from the chemical properties of the proteins to the cellular membranes. Nevertheless, it is implied that the concentration of protein in intracellular water remains constant at about 25 per cent, loss or gain of either component being attended by an equivalent loss or gain of the other. This concept draws a distinction between intracellular and extracellular water which seems to have considerable importance in the physiological interpretation of water exchange. It appears from the studies of Gamble $(9,12,13)$ and others that the interstitial fluids and the intracellular fluids differ not only in composition, but also in function. The former expand and contract within relatively wide limits without serious disorganization of the bodily economy in response to a variety of physiological and pathological influences, apparently acting as a fluid reservoir and perhaps as a buffer for the protection of the intracellular fluids, which are more solicitously protected against comparable fluctuations of volume. Nevertheless, it is quite evident from the same studies, in which determinations of salt exchange have permitted comparatively exact allocation of the water balance, that water and protein do not move to and from the cells in exact proportions. In the diuresis produced by acidifying salts $(12,13)$ and other drugs (14) a certain amount of cellular water is lost without any demonstrable sacrifice of protein or glycogen.

It may be well at this point to abandon theoretical discussion and to examine the origin of the mathematical factors which are almost unquestioningly employed to express the quantitative amounts of water held by the different food stuffs in the body. They are, in general, derived from three sources: metabolism experiments, many of which have been discussed above; tissue analyses; and reasoning by deduction or inference. 
The factor 0.1 , used for fat, is distinguished from the others by the fact that it is so small that it could hardly be verified by metabolism experiments. No one has, as yet, claimed that in experiments sufficiently long to permit the deposition or destruction of a kilo of fat, the gain or loss of $100 \mathrm{cc}$. of water can be determined and allocated with accuracy. Moreover, the distribution of fat differs from that of glycogen and protein. The latter are found chiefly in muscle and active parenchymatous tissue cells, which normally contain only small quantities of fat. Fat is stored predominantly in areolar tissue between parenchymatous cells, in the subcutaneous tissues and in various depots. For this reason it is questionable whether the "water of combination" of fat, in any case, should be placed in the same category as the water held by protein and glycogen. Certainly it should be treated separately when it is desirable to draw a distinction between intracellular and extracellular water. Presumably the fat factor is derived from analyses of fatty tissue. All such analyses are subject to criticism because it is impossible to separate the cellular components of tissue from the interstitial fluid in which they are bathed. In the fat cells themselves fat has the appearance and gives the reactions of pure lipoid material surrounded by a minimal amount of differentiated protoplasm. But even in the densest fatty tissue there are between the cells interstices which seem to contain aqueous fluid similar to that found in the interstitial spaces of other tissues. It is, in the last analysis, imperative that there should be such fluid to act as a vehicle for the mobilization of the fat when it is required for fuel in other parts of the body. That the interstitial water and the water of cellular protoplasm should amount to 10 per cent of the total weight of fatty tissue is not incredible.

Concerning the glycogen factor there has been considerable controversy. According to Bridge and Bridges (18) it was first proposed in 1906 by Zuntz, Loewy, Müller and Caspari (4) and was based on certain experimental data published by Pavy (5) as early as 1860 . Bridge and Bridges, with some reason, take exception to the use of results of analyses made at a time when, as Pavy (19) himself later admitted, methods for the determination of glycogen were not entirely satisfactory. The experiments consisted of comparing the glycogen contents and weights of the livers of rabbits, without direct determinations of water content. The average glycogen increments were related to the average weight increments roughly as 1 to 4 . Bridge and Bridges (18) analyzed the livers of 13 rabbits, which had received a variety of diets, for water, total solids, protein, glycogen and fat. Water content varied from 68.5 to 75.5 per cent and was not related to glycogen, which varied from 0.4 to 10.6 per cent. However, the authors point out that alterations of glycogen in the liver are more or less offset by changes in one or more of the other components, especially protein. From analysis of the data they conclude that their "findings do not substantiate the frequently quoted statement that with every gram of glycogen 3 grams of water are also stored in the body." 
To these statements Puckett and Wiley (20) and MacKay and Bergman (21) have taken exception. The former analyzed the livers of 11 rats for water and glycogen only. Whereas glycogen varied from 0 to 7.6 per cent, water remained within the narrow limits 69.7 to 70.6 per cent with the exception of the liver of one extremely obese rat which contained only 63.9 per cent of water. The relative constancy of the concentration of water compared to that of glycogen convinced the authors that water and glycogen must be retained in relatively equal proportions. The one exception the authors ascribe to the deposition of excessive amounts of fat in the liver. Their correlation holds only if solids other than glycogen do not change. That fat, protein and undetermined solids do change considerably is shown by the analyses of Bridge and Bridges. MacKay and Bergman (21) have also criticized the conclusions of Bridge and Bridges (18). They point out that, if three observations are omitted, increments of glycogen and water parallel one another. They have added analyses of water and glycogen in the livers of 25 rabbits in which they demonstrate a similar relation. They confess that the data do not permit accurate quantitation of the proportions in which glycogen and water are retained, but state that they "do not oppose the frequently quoted statement that with every gram of glycogen 3 grams of water are stored."

Bridge and Bridges (22) in their reply to MacKay and Bergman have somewhat rightly objected to the exception of certain of their animals which MacKay and Bergman omitted from consideration, offering as a reason that they had received peculiar diets. They also call attention to the fact that in only 5 of MacKay and Bergman's animals did the water content of the high glycogen livers exceed that of the low glycogen livers, which varied greatly. Moreover, the five exceptional animals had received large doses of glucose and water by stomach tube. Bridge and Bridges stress a variability in all these experiments which MacKay and Bergman admit. The former do not deny that glycogen, like other solutes, plays some part in holding water, but justifiably contend that the data available do not permit the definition of any exact mathematical relationships between the storage of glycogen and water in the liver. MacKay and Bergman's data, by their own calculations, show a variation from 0 to 9 grams of water per gram of glycogen.

MacKay and Bergman also analyzed the muscles of their animals for glycogen and water. However, the results can not be evaluated because glycogen concentrations never exceeded 1 per cent, while water varied from 71.4 to 79.4 per cent.

Bridge and Bridges (22) also state that in any case the changes of body water that occur when the proportions of fat, protein and carbohydrate in the diet are altered are far too great to be referred to the quantities of water bound to glycogen. In their earlier article (18) they call attention to a fact that has been noted above : in the experiments of Benedict and Milner 
the loss of body water which occurred when a high fat diet was substituted for a high carbohydrate diet was attended by no appreciable destruction of glycogen. In the experiments of Gouin and Andouard (23), which are cited by Benedict and Milner (8), two heifers, when changed from a diet consisting chiefly of legumes to one consisting of hay, straw, molasses, beet roots and ground-nut cake, gained several kilos which they lost again upon returning to the legume diet. In this instance the contrast is not between fat and carbohydrate, but between protein and carbohydrate.

There would seem, then, to be no evidence concerning the water-binding power of glycogen in the body as a whole. Changes in the character of the diet appear to induce alterations in the water content of the body; but it is, as yet, entirely uncertain whether the intracellular or extracellular compartments are chiefly affected by these alterations. If it is the extracellular compartment there is added reason for believing that the water can not be combined with or restrained by glycogen, which is a cellular component.

The analyses of Bridge and Bridges (18) are sufficiently complete to permit some estimation of the proportions of water to the various cellular components. The results of such an examination are presented in Table 4.

TABLE 4

Determined and estimated water in liver. Data of Bridge and Bridges (18)

\begin{tabular}{c|c|c|c}
\hline \hline $\begin{array}{c}\text { Rabbit } \\
\text { number }\end{array}$ & $\begin{array}{c}\text { Observed } \\
\text { water }\end{array}$ & $\begin{array}{c}\text { Calculated water } \\
3 P+3 C+0.1 P\end{array}$ & $\begin{array}{c}\text { Water in fat } \\
\text { free liver }\end{array}$ \\
\cline { 2 - 3 } & per cent & per cent & per cont \\
74 & 72.4 & 71.6 & 73.8 \\
61 & 72.0 & 70.1 & 73.5 \\
64 & 70.8 & 76.7 & 72.6 \\
51 & 70.8 & 78.0 & 73.0 \\
52 & 71.4 & 71.2 & 74.2 \\
55 & 72.7 & 73.3 & 73.7 \\
63 & 74.4 & 63.0 & 76.3 \\
62 & 70.5 & 63.2 & 74.4 \\
11 & 75.0 & 55.0 & 77.0 \\
54 & 73.0 & 64.6 & 77.7 \\
02 & 75.5 & 64.5 & 74.4 \\
01 & 70.5 & 61.7 & 73.2 \\
03 & 68.5 & 70.7 & \\
\hline
\end{tabular}

In the first column are shown the observed concentrations of water in per cent. In the second column appear the water concentrations that would be expected if the 3 food components held water in the proportions indicated by Equation 2 for preformed water. In the third column may be found the concentrations of water estimated for the fat free liver. These are calculated by dividing the observed water values of the first column by the factor,

$$
\frac{100 \text { - observed fat concentration }}{100} \text {. }
$$


The variation in the second column is far greater than that in the first. As far as these experiments are concerned, then, there is little reason to believe that the factors have been well chosen. Least variation is found in the third column. However, the difference between this and the first column lies entirely in the fact that the low value found in the last animal with the extremely fat liver is brought into the range of the other animals. This would suggest that fat is, so to speak, extraprotoplasmic and unrelated to water, which is governed by the other solutes. Whether this fat was within or without the cells is unknown. Whether more exact analysis of such a small body of data is justifiable is uncertain. The concentration of water in the fat-free liver would seem, however, to be more closely related to the total solids than to protein + glycogen because the liver with the highest undetermined solids contained the smallest amounts of protein and glycogen.

The ratios of protein + glycogen to water in the fat-free liver vary from 2.4 to 3.7, averaging 3.1. At first sight this would seem to support the contention that 3 is a satisfactory factor for the calculation of the average amounts of water held by protein and glycogen in liver, although it is impossible to determine from so few analyses the relative effects of the two. In fact these may not be specific. Both protein and glycogen may act as so much undifferentiated solute as far as water concentration is concerned. However, as in all tissue analyses, an indeterminable amount of extracellular substance must have been included in the samples. Ultimately, then, the figures for intracellular water concentrations are maximal and the actual ratio of water to glycogen and protein in the cells must be smaller.

Those who have not attempted to differentiate intracellular and extracellular water might claim that if liver is a representative tissue the constancy of the relation between water and the chief solutes, glycogen and protein, justifies the conception that water and these food stuffs are linked in metabolism. When, however, this constancy is examined more closely, it is found to afford little grounds for such satisfaction. If the water concentration varies from $\mathbf{7 2 . 6}$ to 77.8 per cent in the liver, one can only conclude that, under certain circumstances 19 per cent of the solids of the organ may be sacrificed without any water, or 7 per cent of the water without any solids.

The factors used to represent water bound by protein have, like that for glycogen, been used by some to estimate total water held by protein in the body and by others as a measure of intracellular, as distinguished from extracellular, water. They have been derived from certain inferences concerning the total amounts of protein and water in the human body and an analysis of human muscle, published by Katz (11). Rubner (24), in an attempt to estimate the total cellular surface area of the body, made certain assumptions concerning the magnitudes of the various compartments of the 
body and the distribution of protein and fluids in these compartments. There is no evidence that these estimates are more than clever guesses, although the authority with which they have been perpetuated by Lusk (7) and others would give the impression that they were results of painstaking analyses. In these calculations Rubner (25) estimates that in a normal man there are 30 grams of nitrogen (or 187.5 grams of protein) per kilo of body weight. ${ }^{1}$ If, as is generally claimed, 70 per cent of the body is composed of water, this would mean that the concentration of protein in body water is about 27 per cent.

It was from this figure for body nitrogen and Katz' (11) analysis of human muscle that Benedict (6) derived the factor for "water of flesh," 3.9, which has been mentioned above (see Table 2). Katz found 729 grams of water per kilo of muscle. By combining this figure with Rubner's estimate of the protein content of the body as a whole, Benedict concludes that 1 gram of protein combines with $727 / 187.5=3.9$ grams of water to form 4.9 grams of flesh. In the first place in these calculations Rubner's estimate of the nitrogen content of the human body is accepted and combined with analytical data of an entirely different kind. ${ }^{2}$ Moreover, Benedict seems to assume that the ratio of water to protein in muscle is the same as that in the body as a whole and that all the water of the body is bound by protein. However, at the bottom of page 70 , in the analysis of experiment 75 , because he recognizes that water is swept out more rapidly in the earlier stages of a fast, while water and protein losses more nearly agree with his predictions as the fast progresses, he says, "It seems, therefore, that the body must have a large residuum of water other than that in muscle and glands." This statement seems to imply that only the water in " muscle and glands" is bound with protein in which case the factor 3.9 must be too large.

It has already been shown that Rubner's estimate of the protein content of the body, if combined with the generally accepted factor for body water content, 70 per cent, gives a value of 26.8 per cent for the average concentration of protein in the aqueous media of the body, or approximately a ratio of protein : water $=1: 3$. Analyses of various parenchymatous animal tissues yield approximately the same figures. (In the liver the ratio is lower and more variable, because of the large glycogen content and the fact that water is more nearly related to solids than to protein. In this organ the ratio of water to protein + glycogen approximates the ratio of water to protein in other tissues which contain only small amounts of glycogen.) The results of the two methods of calculation are quite incompatible. If

1 These estimates are based on determinations of the protein and water content of pigeon muscles. In the same article he points out that the water and protein of muscle may vary widely quite independently of one another.

2 It should be noted that, according to Rubner's figures, 1 gram of protein is equivalent to $1000 / 187.5=5.0$ grams of flesh. 
the ratio of protein to water in the aqueous media of the body as a whole is $1: 3$, it evidently must be higher than this in muscle and other parenchymatous cells to equalize the known low concentrations in which protein appears in serum, lymph and interstitial fluids. This variability of the relation of protein to water, in fact, makes the entire theory that the water of the body as a whole is restrained by protein extremely improbable. It would force one to infer that the proteins in different media had various water binding powers. Moreover, one would be compelled to believe, in order to explain exchanges between media within the body or between the blood and the alimentary canal, that the water binding powers of proteins in these media were continually changing in response to physiological needs of the bodily economy. This would, of itself, nullify all attempts at prediction in metabolic experiments. Even if it had not been demonstrated that in serum, at least, all the water is free $(15,16)$ the hypothesis that water of the body as a whole is restrained by combination with protein seems to be untenable. (The amounts of glycogen and fat in most of these media are so inconsiderable as to be insignificant in this connection.)

If water is restrained by protein, then, it would seem likely that the restraining force is a physiological rather than a chemical or physical one, representing merely a general tendency in all media to maintain a relatively constant dilution of solutes, of which protein makes up the major fraction in point of view of mass and volume. This is merely an indirect way of distinguishing between intracellular and extracellular water. Because the cells contain greater concentrations of protein and, presumably, bear the chief brunt of nutritional disturbances, preformed water, in the sense in which Newburgh and Johnston $(1,2)$ employ the term, would become synonymous with the intracellular water of Gamble (9). For the estimation of this water most observers, including Gamble, have depended upon Katz (11), who has published analyses of the muscle of a criminal, examined immediately after death. This muscle contained 72.7 per cent by weight of water which, considering protein as the chief solid component, would give a protein to water ratio of about $1: 3$. The fallacy of estimating the composition of parenchymatous cells from analyses of tissue containing an admixture of interstitial substance has already been mentioned. Certainly it is fair to say that the actual percentage of protein in the muscle cells must have been higher and that of water lower than Katz' analyses indicate. The possible magnitude of the errors will be discussed in another connection. Suffice it to say that the factor relating cell protein to water must be smaller than 3 .

\section{DISCUSSION}

If preformed water is intracellular water, Newburgh and Johnston's treatment of it and their inclusion of the term in their general water balance calculations imply that even if the water of solution of cellular pro- 
tein is not discharged from the body when protein is destroyed, it is at least eliminated from the cells. At least they would seem to believe that the destruction of protein alters its nature from that of combined water to free water, which in physiological terms could only mean transfer from the intracellular to the extracellular compartment. On this point their own experiments can throw no light nor can the majority of metabolism experiments that have been cited above, because they afford no independent criteria by which the source or nature of the water which takes part in the water balance may be distinguished. Benedict's (10) study of $L$ during 31 days of starvation and Gamble's $(9,12,13)$ experiments on the effect of starvation and of diuretics offer such criteria in parallel determinations of the electrolyte exchange. Gamble has further determined the concentrations of electrolytes in the serum. These experiments, however, only prove, what might have been reasonably expected from available tissue analyses and other aspects of physiology, that if there is a tendency for water and protein of cells to move together, their association is strictly conditioned.

In this connection some information might be secured by consideration of the red blood cell, which has been more extensively studied than any other human cell because it is readily accessible and can be separated from its environmental interstitial substance, plasma. Although the water concentration of normal blood as a whole is about 83.9 per cent by volume that of the separated red blood cells is only about 72.3 per cent by volume (66.2 per cent by weight). ${ }^{3}$ This is lower than the values usually given for muscle cells and other tissue cells and would yield a water to protein ratio nearer 2 than 3 . This does not necessarily mean that the red cell is more solid than the muscle cell. The latter, isolated from its interstitial substance, may have a similar composition. In anemia the protein and water concentrations in the red blood cells depart considerably from these averages. One might interpret this as an indication that cellular protein does not completely dominate cellular water content as is implied in the concept of " preformed water." Furthermore the water concentration of the red cells may be greatly altered both in the test tube and in the body by osmotic pressure disturbances which do not affect their absolute protein content, and there is no reason for believing that other cells in the body do not respond in a similar manner to osmotic influences.

\section{SUMMARY AND CONCLUSIONS}

There is little evidence that water is chemically or physically held in combination by protein, fat or carbohydrate in the body. There appears to be a general tendency for the relations of water to solutes in all media of the body to remain constant within rather broad limits. There are no

3 The figures here given depend upon extensive analyses made in this department by A. J. Eisenman, as yet unpublished. 
grounds for believing that this is more than a part of the general principle of biological automatism. The factors which are used to express the rough average ratios of water to solutes in the body have been derived from scanty and conflicting data or estimated by inferences which are hardly better than guesses, and can not stand careful analysis. Changes of body water after alterations of diet can not be related to accessions or losses of glycogen or protein, but must depend upon more subtle influences which are, as yet, undetermined. There seems to be no evidence that fat holds water. The physiological distinction between intracellular and extracellular water and separate movements of the two seems to have some value. The hypothesis that the proportion of protein or protein + glycogen to water in the cells remains constant, with its implication that destruction of these substances inevitably results in the discharge from the cells, if not from the body, of the water in which they were dissolved, has little experimental support. Certainly such an association between these solvents and water is strictly conditioned. To study the nature of the conditioning factors, as Gamble has done, would seem more logical than to make an assumption that is obviously contrary to fact under a great variety of conditions. The factor which Gamble and others have accepted as representing the ratio of water to protein in muscle cells is derived from analyses of tissue containing not only muscle cells but an admixture of interstitial substance which, presumably, contains a higher proportion of water. It follows that this factor, 3 , is too high. (Incidentally it has been pointed out that this is approximately the ratio of protein to water in the whole body, according to the estimates of Rubner.) When water balance is determined by purely metabolic methods, as in the procedure proposed by Newburgh and Johnston, it is impossible to distinguish intracellular and extracellular water. As their term preformed water can have no significance if interpreted in any other way than as intracellular water, there is no valid reason for retaining it in their calculations. If metabolic methods alone have any value, it consists merely in permitting the estimation of the water exchange between the organism and the external environment.

\section{BIBLIOGRAPHY}

1. Newburgh, L. H., Johnston, M. W., and Falcon-Lesses, M., J. Clin. Invest., 1929-30, viii, 161. Measurement of Total Water Exchange.

Newburgh, L. H., and Johnston, M. W., J. Clin. Invest., 1929-30, viii, 197. The Nature of Obesity.

2. Newburgh, L. H., and Johnston, M. W., The Exchange of Energy between Man and the Environment. Charles C. Thomas, Baltimore, 1930.

3. Peters, J. P., Kydd, D. M., and Lavietes, P. H., J. Clin. Invest., 1933, xii, 689. A Note on the Calculation of Water Exchange.

4. Zuntz, N., Loewy, A., Müller, F., and Caspari, W., Höhenklima und Bergwanderungen. Berlin, 1906, p. 114. Cited by Bridge, E. M., and Bridges, E. M. (18).

5. Pavy, F. W., Phil. Tr. Roy. Soc. London, 1860, cl, 595. Researches on Sugar Formation in the Liver. 
6. Benedict, F. G., Carnegie Institution of Washington, 1907, Publication No. 77. The Influence of Inanition on Metabolism.

7. Lusk, G., The Elements of the Science of Nutrition. W. B. Saunders Company, 1928, 4th ed.

8. Benedict, F. G., and Milner, R. D., U. S. Dept. Agriculture, Office of Exper. Stations, 1907, Bull. 175. Experiments on the Metabolism of Matter and Energy. 1903-04.

9. Gamble, J. L., Ross, G. S., and Tisdall, F. F., J. Biol. Chem., 1923, lvii, 633. The Metabolism of Fixed Base during Fasting.

10. Benedict, F. G., Carnegie Institution of Washington, 1915, Publication No. 203. A Study of Prolonged Fasting.

11. Katz, J., Arch. f. d. ges. Physiol., 1896, 1xiii, 1. Die mineralischen Bestandtheile des Muskelfleisches.

12. Gamble, J. L., Ross, G. S., and Tisdall, F. F., Am. J. Dis. Child., 1923, xxv, 455. Studies of Tetany. I. The Effect of Calcium Chloride Ingestion on the Acid-base Metabolism of Infants.

Gamble, J. L., and Ross, G. S., Am. J. Dis. Child., 1923, xxv, 470. Studies of Tetany. II. The Effect of Ingestion of Hydrochloric Acid Producing Substances on the Acid-base Metabolism of an Infant and the Probable Manner of their Action in the Treatment of Tetany.

13. Gamble, J. L., Blackfan, K. D., and Hamilton, B., J. Clin. Invest., 1925, i, 359. A Study of the Diuretic Action of Acid Producing Salts.

14. Blumgart, H. L., Gilligan, D. R., Levy, R. C., and Brown, M. G., Tr. A. Am. Physicians, 1932, xlvii, 304. The Effect of Diuretics on Water and Salt Metabolism.

15. Sunderman, F. W., J. Biol. Chem., 1932, xcvi, 271. The Osmotic Behavior of Water and Blood Serum.

16. Greenberg, D. M., J. Biol. Chem., Proc., 1932, xcvii, p. xlv. Ultrafiltration. II. Bound Water (Hydration) of Biological Colloids.

17. Hill, A. V., Adventures in Biophysics. University of Pennsylvania Press, 1931, p. 53.

18. Bridge, E. M., and Bridges, E. M., J. Biol. Chem., 1931, xciii, 181. The Relation of Glycogen to Water Storage in the Liver.

19. Pavy, F. W., The Physiology of the Carbohydrates. Churchill, London, 1895 , p. 114.

20. Puckett, H. L., and Wiley, F. H., J. Biol. Chem., 1932, xcvi, 367. The Relation of Glycogen to Water Storage in the Liver.

21. MacKay, E. M., and Bergman, H. C., J. Biol. Chem., 1932, xcvi, 373. The Relation between Glycogen and Water Storage in the Liver.

22. Bridge, E. M., and Bridges, E. M., J. Biol. Chem., 1932, xcvi, 381. The Relation of Glycogen to Water Storage in the Liver. A Reply to the Communications of Puckett and Wiley and of MacKay and Bergman.

23. Gouin, A., and Andouard, P., Compt. rend. Soc. de biol., 1905, lviii, 813. Influence du régime alimentaire sur l'hydration des tissus du corps des bovidés.

24. Rubner, M., Arch. f. Anat. u. Physiol., 1913 (Physiol. Abt.), p. 240. Betrachtungen über die Resorptionsvorgänge der Organzellen.

25. Rubner, M., Arch. f. Anat. u. Physiol., 1911 (Physiol. Abt.), p. 67. Uber den Eweissansatz. 